O. S. Pokotylo', M. D. Kuhtyn', O. A. Pokotylo², T. Ya. Yaroshenko², M. I. Koval' IVAN PULIUY TERNOPIL NATIONAL TECHNICAL UNIVERSITY' I. YA. HORBACHEVSKY TERNOPIL STATE MEDICAL UNIVERSITY²

\title{
LIPOGENESIS IN ADIPOSE TISSUE OF THE LABORATORY ANIMALS AFTER LOADING WITH CHOLESTEROL
}

The intensity of synthesis of different lipids classes was studied in vitro (fatty acids, cholesterol, phospholipids and acylglycerols) in the homogenates of the adipose tissue after a single daily loading of rats and guinea pigs with the cholesterol $(300 \mathrm{mg} / \mathrm{kg}$ body weight) during 30 days period. For this purpose, the radioactivity of lipid fractions in the homogenates of adipose tissue of the rats and guinea pigs was measured, while homogenates were incubated separately with $\left[6-{ }^{14} \mathrm{C}\right]$ glucose, $\left[2-{ }^{14} \mathrm{C}\right]$ lysine or $\left[1-{ }^{14} \mathrm{C}\right]$ palmitic acid. The inhibitory effect of cholesterol was established by increasing its level in the diet of rats and guinea pigs on all classes of lipid synthesis in adipose tissue in vitro when $\left[6-{ }^{14} \mathrm{C}\right]$ glucose and $\left[2-{ }^{14} \mathrm{C}\right]$ lysine were used as precursors, and on the synthesis of cholesterol when $\left[1-{ }^{14} \mathrm{C}\right]$ palmitic acid was used as precursor.

KEY WORDS: lipids, cholesterol, rats, guinea pigs, adipose tissue, hypercholesterolemia.

INTRODUCTION. In laboratory animals the experimental hypercholesterolemia is mainly associated with atherosclerosis and used as a laboratory model for studying the pathogenesis of cardiovascular and metabolic pathology, such as coronary heart disease, angina, and myocardial infarction [1, 6, 8]. According to modern ideas that have developed as a result of numerous studies, the increasing level of cholesterol in the diet of animals leads to an increase in its content in plasma lipoproteins and the development of vascular pathology [2, 3, 6].

Effect of experimental hypercholesterolemia in cholesterol and triacylglycerol metabolism, including their synthesis in individual organs and tissues of laboratory animals, is much less studied $[4,11]$. The influence of experimental hypercholesterolemia on the degree of consumption of various precursors of cholesterol and fatty acids in their synthesis in individual organs and tissues remains unclear.

The aim of this study was to investigate the effect of experimental hypercholesterolemia in rats and guinea pigs with a load of cholesterol on synthesis of cholesterol and other lipid classes in adipose tissue using different precursors (glucose, palmitic acid, lysine) labeled with radioactive carbon. This scheme is due to the central position

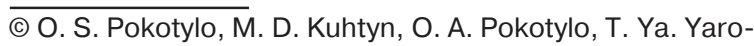
shenko, M. I. Koval, 2015. of studies of adipose tissue in the synthesis of reserve lipids [11].

METHODS OF RESEARCH. Studies were conducted on 2 groups of male guinea pigs weighing 360-380 grams and 2 groups of male albino rats weighing 180-200 grams, 4 animals in each group, which were held in the vivarium. Animals of the 1st (control) group of both species were fed a standard diet. Animals of the $2^{\text {nd }}$ group (D) developed hypercholesterolemia caused by feeding them with cholesterol diet in the amount of $300 \mathrm{mg} / \mathrm{kg}$ of body weight per day. The duration of the experiment was 30 days. After the experiment, the animals from all groups were sacrificed by decapitation under ether anesthesia, and their brain samples were used for the analysis. Sections of the brain about the size of $1 \times 1 \times 1 \mathrm{~mm}$ and $100 \mathrm{mg}$ were transferred to hatching vessels with phosphate Krebs-Ringer buffer (the ratio of mass to volume of tissue to buffer was - 1:10, pH 7.5 , the gas phase - air), to which was added 1 micro Curie $\left[6-{ }^{14} \mathrm{C}\right.$ ] glucose, $\left[2-{ }^{14} \mathrm{C}\right]$ lysine or $\left[1-{ }^{14} \mathrm{C}\right]$ palmitic acid [10] and incubated for $60 \mathrm{mi}-$ nutes in ultra-termostat at $38{ }^{\circ} \mathrm{C}$ with constant stirring [5]. After the incubation, the suspension was centrifuged. The precipitate was washed with $10 \mathrm{ml}$ of distilled water to remove residual isotope and again pelleted by centrifugation [5]. The lipids were extracted from the precipitate with a mixture 
of chloroform-methanol (volume ratio 2:1) using Folcha method. They were fractionated into classes by thin layer chromatography on silica gel in the system hexane diethyl ether glacial acetic acid (ratio 70:30:1, respectively) [5], and their radioactivity was determined in a liquid scintillation counter Rovetta ("LKV", Sweden) in toluene scintillator. The obtained data were statistically processed.

RESULTS AND DISCUSSION. The data in Table 1 show that the radioactivity of all classes of lipids in adipose tissue homogenates of the rats in the second group with $\left[6-{ }^{14} \mathrm{C}\right]$ glucose was much lower $(p<0.001)$ comparing to the homogenates of adipose tissues of the $1^{\text {st }}$ group. These data indicate the inhibitory effect of exogenous cholesterol while raising its level in the diet of animals on its synthesis and the synthesis of all other classes of lipids, including triacylglycerols, in adipose tissue of rats. The reason for this, according to the obtained results, is exogenous cholesterol inhibition with increasing its level in the diet of animals' synthesis of acetyl-CoA, which is a precursor of cholesterol and fatty acids, by the feedback mechanism.

Acetyl-CoA in animal tissues, including adipose tissue, is formed by the decarboxylation of pyruvic acid, during glucose metabolism using aerobic process. Synthesis inhibition by a feedback mechanism is well known, which is described by the decrease in activity of enzymes that catalyze the formation of its predecessors synthesis into the end products, which happens during the conditions of the experiment such as exogenous cholesterol presence.

Explanation is consistent with results as we detected significantly less radioactivity of cholesterol and all other classes of lipids and fatty acids in adipose tissue homogenates of the rats in group 2 with $\left[2-{ }^{14} \mathrm{C}\right]$ lysine $(p<0.001)$, compared to the radioactivity of lipids synthesized in the homogenates of adipose tissue from group 1. As you know, the end product of metabolism of the carbon skeleton after deamination of lysine in animal tissues is Acetyl-CoA, which can be oxidized in the tricarboxylic acid cycle, and also is used in the synthesis of fatty acids and cholesterol. Reduced cholesterol synthesis was also found in adipose tissue of animals from group two during the incubation of homogenates with $\left[1-{ }^{14} \mathrm{C}\right]$ palmitic acid. Radioactivity of free cholesterol during the incubation of adipose tissue homogenates from rats in group two with $\left[1-{ }^{14} \mathrm{C}\right]$ palmitic acid was twice smaller $(p<0.001)$ than during the incubation of homogenates from animals of group one, while the difference in radioactivity of triacylglycerols was absent, and the radioactivity of phospholipids - higher. These data suggest that during extra load of cholesterol in rat adipose tissue of white rats in vitro oxidation decreases $\left[1-{ }^{14} \mathrm{C}\right]$ palmitic acid and the use of acetyl-CoA formed in the synthesis of cholesterol.

In general, the obtained results indicate inhibitory effect of exogenous cholesterol when added to the diet of rats on the formation of acetylCoA and its use in the synthesis of fatty acids and cholesterol from different precursors not only in the liver, brain and mucous thin guts under conditions in vitro [9], but also in adipose tissue. Reduced synthesis of fatty acids in adipose tissue of animals with hypercholesterolemia leads to a decrease in their use during the synthesis of triacylglycerols and phospholipids and in the etherification of the cholesterol.

The data in Table 2 show that the intensity of lipid synthesis in adipose tissue of guinea pigs with hypercholesterolemia is dramatically reduced compared to the intensity of their synthesis in animals from the control group when $\left[6-{ }^{14} \mathrm{C}\right]$ glucose is used as a lipid precursor. Thus, the radioactivity of total lipids synthesized by adipose tissue

Table 1 - The radioactivity of certain classes of lipids synthesized by adipose tissue of rats in homogenates after incubation with $\left[6-{ }^{14} \mathrm{C}\right]$ glucose, $\left[1-{ }^{14} \mathrm{C}\right]$ palmitic acid and $\left[2-{ }^{14} \mathrm{C}\right]$ lysine $(\mathrm{M} \pm \mathrm{m}, \beta$-decays/100 $\mathrm{mg}$ wet tissue/min, $\mathrm{n}=4)$

\begin{tabular}{|c|c|c|c|c|c|c|}
\hline \multirow{3}{*}{$\begin{array}{c}\text { The class } \\
\text { of lipids }\end{array}$} & \multicolumn{6}{|c|}{ Group of animals } \\
\hline & \multicolumn{2}{|c|}{$\begin{array}{l}{\left[6-{ }^{14} \mathrm{C}\right]} \\
\text { glucose }\end{array}$} & \multicolumn{2}{|c|}{$\begin{array}{c}{\left[1-^{14} \mathrm{C}\right]} \\
\text { palmitic acid }\end{array}$} & \multicolumn{2}{|c|}{$\begin{array}{c}{\left[2-{ }^{-14} \mathrm{C}\right]} \\
\text { lysine } \\
\end{array}$} \\
\hline & control & treatment & control & treatment & control & treatment \\
\hline Phospholipids & $1135 \pm 83$ & $82 \pm 6^{\star}$ & $311 \pm 19$ & $549 \pm 32^{\star}$ & $844 \pm 49$ & $158 \pm 7^{\star}$ \\
\hline Mono and diacylglycerol & $562 \pm 27$ & $79 \pm 4^{\star}$ & $488 \pm 31$ & $528 \pm 38$ & $442 \pm 31$ & $81 \pm 5^{\star}$ \\
\hline Free cholesterol & $1056 \pm 63$ & $86 \pm 4^{*}$ & $402 \pm 29$ & $586 \pm 19^{*}$ & $500 \pm 36$ & $138 \pm 9^{*}$ \\
\hline Free fatty acids & $4244 \pm 222$ & $111 \pm 9^{*}$ & $997 \pm 45$ & $924 \pm 40$ & $1287 \pm 66$ & $222 \pm 14^{*}$ \\
\hline Triacylglycerol & $3805 \pm 195$ & $87 \pm 3^{*}$ & $1144 \pm 39$ & $1137 \pm 68$ & $3095 \pm 172$ & $95 \pm 5^{*}$ \\
\hline Etherified cholesterol & $1345 \pm 88$ & $81 \pm 5^{\star}$ & $1064 \pm 57$ & $1004 \pm 55$ & $980 \pm 64$ & $104 \pm 3^{*}$ \\
\hline General lipids & $12147 \pm 644$ & $528 \pm 33^{\star}$ & $4406 \pm 198$ & $4731 \pm 216$ & $7151 \pm 403$ & $799 \pm 62^{*}$ \\
\hline
\end{tabular}

Note. Here and in Table 2: * - the probability of differences between parameters is $p<0.005$. 
of guinea pigs in group two with hypercholesterolemia was 3.21 times less than the radioactivity of total lipids in guinea pigs from the 1st (control) group.

Studies have shown that radioactivity of phospholipids, free cholesterol+diacylglycerols, free fatty acids, triacylglycerols and etherified cholesterol synthesized in the tissues in group two during the incubation with $\left[6-{ }^{14} \mathrm{C}\right]$ glucose was less by $1.64 ; 1.81 ; 2.36 ; 10.07$ and 2.26 times respectively, compared with the animals of the 1st control group.

The results are consistent with the data on the inhibition of lipid synthesis in adipose tissue of rats with hypercholesterolemia when $\left[6-{ }^{14} \mathrm{C}\right]$ glucose is used as a precursor for lipids formation. This can be explained by inhibitory effect on cholesterol formation by acetyl-CoA from pyruvate formed during the metabolism of glucose in tissues of animals with hypercholesterolemia by a feedback mechanism. This mechanism includes, reduction in substrate concentration providing synthesis on the one hand, cholesterol, and the other - fatty acids. As a result, the intensity decreases not only for the synthesis of fatty acids and cholesterol and other lipid classes.

The data in Table 2 show that most of the $\left[1-{ }^{-14} \mathrm{C}\right]$ palmitic acid is used in the adipose tissue of guinea pigs in the synthesis of phospholipids and triacylglycerols. Thus, their radioactivity was respectively 23.6 and $18.5 \%$ of the total radioactivity for the lipids, and the total radioactivity of diacylglycerols and free cholesterol amounted to $18.5 \%$, free fatty acids to $23.7 \%$, etherified cholesterol - to $15.8 \%$ of radioactivity for total lipids.

Table 2 - The radioactivity of certain classes of lipids synthesized by adipose tissue in the studied guinea pigs during the incubation with $\left[6-{ }^{14} \mathrm{C}\right]$ glucose, $\left[1-{ }^{14} \mathrm{C}\right]$ palmitic acid and $\left[2-{ }^{14} \mathrm{C}\right]$ lysine $(\mathrm{M} \pm \mathrm{m}, \beta$-decays/100 $\mathrm{mg}$ wet tissue/min, $\mathrm{n}=4)$

\begin{tabular}{||l|c|c|c|c|c|c||}
\hline \multirow{2}{*}{ The class of lipids } & \multicolumn{7}{|c|}{ Group of animals } \\
\cline { 2 - 7 } & control & treatment & control & treatment & control & treatment \\
\hline Phospholipids & $1280 \pm 85$ & $780 \pm 47^{\star}$ & $976 \pm 79$ & $1116 \pm 65$ & $921 \pm 69$ & $724 \pm 51$ \\
\hline $\begin{array}{l}\text { Diacylglycerols + free } \\
\text { cholesterol }\end{array}$ & $858 \pm 53$ & $474 \pm 53^{\star}$ & $776 \pm 64$ & $860 \pm 99$ & $612 \pm 45$ & $446 \pm 21^{\star}$ \\
\hline Free fatty acids & $1888 \pm 107$ & $800 \pm 33^{\star}$ & $992 \pm 89$ & $1080 \pm 68$ & $499 \pm 46$ & $446 \pm 28$ \\
\hline Triacylglycerol & $4411 \pm 289$ & $438 \pm 28^{\star}$ & $773 \pm 38$ & $580 \pm 19^{\star}$ & $897 \pm 51$ & $436 \pm 31^{\star}$ \\
\hline Etherified cholesterol & $1013 \pm 69$ & $448 \pm 21^{\star}$ & $661 \pm 53$ & $784 \pm 44$ & $619 \pm 44$ & $458 \pm 38^{\star}$ \\
\hline General lipids & $9450 \pm 620$ & $2940 \pm 144^{\star}$ & $4178 \pm 343$ & $4420 \pm 267$ & $3348 \pm 239$ & $2510 \pm 129^{\star}$ \\
\hline
\end{tabular}

From the data in Table 2 we can show that the difference in the intensity of lipid synthesis in adipose tissue of guinea pigs in group two with hypercholesterolemia when $\left[1-{ }^{14} \mathrm{C}\right]$ palmitic acid is used as a lipid precursor compared to the intensity of their synthesis in animals from group one does not valid. These data indicate a lack of inhibitory effect of hypercholesterolemia on lipid synthesis in adipose tissue of guinea pigs with exogenous fatty acids. This is consistent with the results obtained by us about the lack of inhibitory effect of hypercholesterolemia on the synthesis of lipids with $\left[1-{ }^{-14} \mathrm{C}\right]$ palmitic acid in adipose tissue of rats.

However, the radioactivity of phospholipids synthesized by adipose tissue of guinea pigs of group one during the incubation with $\left[2-{ }^{14} \mathrm{C}\right]$ lysine was $15.2 \%$, diacylglycerols+cholesterol $-12.7 \%$, free fatty acids $-24.5 \%$, triacylglycerols $-36.5 \%$, etherified cholesterol $-11.0 \%$ of the radioactivity for the total lipids. In general, as shown by our study, catabolism of $\left[2-{ }^{14} \mathrm{C}\right]$ lysine and degree obtained with the use of acetyl-CoA in the synthesis of fatty acids and cholesterol in adipose tissue of guinea pigs is much higher than in the brain [7].

Thus obtained results show the inhibitory effect of exogenous cholesterol when added to the diet of rats and guinea pigs on the formation of acetyl-CoA and its use in the synthesis of fatty acids and cholesterol from various precursors in adipose tissue. Reduced synthesis of fatty acids in adipose tissue of animals with hypercholesterolemia leads to a decrease in their use in the synthesis of triacylglycerols and phospholipids and cholesterol etherification.

CONCLUSIONS. Feeding white rats and guinea pigs with standard feed additives in the amount of cholesterol of $300 \mathrm{mg} / \mathrm{kg}$ body weight per day leads to a sharp decrease in the intensity of synthesis of all classes of lipids in adipose tissue in vitro when $\left[6-{ }^{-14} \mathrm{C}\right]$ glucose and $\left[2-{ }^{14} \mathrm{C}\right]$ lysine are used as precursors, and to a reduction in the intensity of synthesis of cholesterol when $\left[1-{ }^{14} \mathrm{C}\right]$ palmitic acid is used as a precursor. 


\section{REFERENCES}

1. Brain Insulin Controls Adipose Tissue Lipolysis and Lipogenesis / Thomas Scherer, James O'Hare, Kelly Diggs-Andrews [et al.] // Cell Metabolism. 2011. - 13, № 2. - P. 183-194.

2. Lafontan M. Lipolysis and lipid mobilization in human adipose tissue / M. Lafontan, D. Langin // Prog. Lipid Res. - 2009. - 48. - P. 275-297.

3. Maternal hyperholesterolemia and treatment during pregnancy influence the long-term progression of atherosclerosis in offspring of rabbits / W. Palinski, F. D'Armiento, J. Witztum [et al.] // J. Circ. Res. 2001. - № 89 (11). - P. 991-996.

4. Trans fatty acids and cholesterol metabolism: mechanistic studies in rats and rabbits fed semipurified diets / L. Gatto, M. Lyons, A. Brown, S. Samman // Int. J. Food Sci. Nutr. - 2001. - 52, № 5. - C. 435-441.

5. Кейтс М. И. Техника липидологии / М. И. Кейтс. - М. : Мир, 1975. - 282 с.

6. Климов А. Н. Обмен липидов и липопротеидов и его нарушения / А. Н. Климов, Н. Г. Никульчева. СПб. : Питер Ком., 1999. - 512 с.
7. Ліпогенез і холестерологенез у головному мозку лабораторних тварин після навантаження холестеролом / О. С. Покотило, М. Д. Кухтин, М.І. Коваль, Т. Я. Ярошенко // Наукові записки Тернопільського національного педагогічного університету. Серія “Біологія". - 2014. - № 4 (61). С. 147-152.

8. Методические рекомендации по изучению гиполипидемических и противоатеросклеротических средств / [Н. А. Гончарова, Л. Т. Малая, В. А. Бобров и др.]. - К. : Фармакологический комитет МЗ Украины, 1996. - 28 с.

9. Покотило О. С. Синтез ліпідів у тканинах білих щурів при навантаженні холестеролом / О. С. Покотило, В. Г. Янович // Біологія тварин. - 2004. - 7, № 1-2. - С. 39-42.

10. Прохорова М. И. Методы биохимических исследований / М. И. Прохорова. - Л. : Изд-во ЛГУ, 1982. - 222 с

11. Янович В. Г. Обмен липидов у животных в онтогенезе / В. Г. Янович, П. З. Лагодюк. - М. : Агропромиздат, 1991. - 316 с.

О. С. Покотило ${ }^{1}$, М. Д. Кухтин ${ }^{1}$, О. О. Покотило ${ }^{2}$, Т. Я. Ярошенко ${ }^{2}$, М. І. Коваль $^{2}$ ТЕРНОПІЛЬСЬКИЙ НАЦІОНАЛЬНИЙ ТЕХНІЧНИЙ УНІВЕРСИТЕТ ІМЕНІ ІВАНА ПУЛЮЯ ТЕРНОПІЛЬСЬКИЙ ДЕРЖАВНИЙ МЕДИЧНИЙ УНІВЕРСИТЕТ ІМЕНІ І. Я. ГОРБАЧЕВСЬКОГО 2

\section{ЛІПОГЕНЕЗ У ЖИРОВІЙ ТКАНИНІ ЛАБОРАТОРНИХ ТВАРИН ПІСЛЯ НАВАНТАЖЕННЯ ХОЛЕСТЕРОЛОМ}

\section{Резюме}

Досліджено in vitro інтенсивність синтезу ліпідів різних класів (жирних кислот, холестеролу, фосфоліпідів і ацилгліцеролів) у гомогенатах жирової тканини після одноразового щоденного впродовж 30 діб навантаження білих щурів і морських свинок холестеролом (300 мг/кг маси тіла). Для цього в гомогенатах жирової тканини білих щурів і морських свинок, які інкубували окремо із $\left[6-{ }^{14} \mathrm{C}\right]$ глюкозою, $\left[2-{ }^{14} \mathrm{C}\right]$ лізином або [1- $\left.{ }^{14}\right]$ пальмітиновою кислотою, визначали радіоактивність ліпідних фракцій. Встановлено інгібуючий вплив холестеролу за умов підвищення його рівня в раціоні білих щурів і морських свинок на синтез всіх класів ліпідів у жировій тканині in vitro при використанні як попередників $\left[6-{ }^{14} \mathrm{C}\right]$ глюкози і $\left[2-{ }^{14} \mathrm{C}\right]$ лізину та на синтез холестеролу при застосуванні як попередника $\left[1-{ }^{14} \mathrm{C}\right]$ пальмітинової кислоти.

КЛЮЧОВІ СЛОВА: ліпіди, холестерол, щури, морські свинки, жирова тканина, гіперхолестеролемія. 


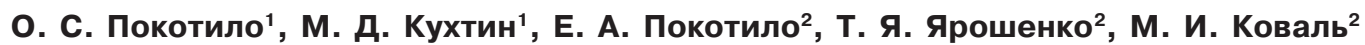
ТЕРНОПОЛЬСКИЙ НАЦИОНАЛЬНЫЙ ТЕХНИЧЕСКИЙ УНИВЕРСИТЕТ ИМЕНИ ИВАНА ПУЛЮЯ ТЕРНОПОЛЬСКИЙ ГОСУДАРСТВЕННЫЙ МЕДИЦИНСКИЙ УНИВЕРСИТЕТ ИМЕНИ И. Я. ГОРБАЧЕВСКОГО

\section{ЛИПОГЕНЕЗ В ЖИРОВОЙ ТКАНИ ЛАБОРАТОРНЫХ ЖИВОТНЫХ ПОСЛЕ НАГРУЗКИ ХОЛЕСТЕРОЛОМ}

\section{Резюме}

Исследована in vitro интенсивность синтеза липидов различных классов (жирных кислот, холестерола, фосфолипидов и ацилглицеролов) в гомогенатах жировой ткани после однократной ежедневной в течение 30 суток нагрузки белых крыс и морских свинок холестеролом (300 мг/кг массы тела). Для этого в гомогенатах жировой ткани белых крыс и морских свинок, которые инкубировали отдельно с $\left[6-{ }^{14} \mathrm{C}\right]$ глюкозой, $\left[2-{ }^{14} \mathrm{C}\right]$ лизином или $\left[1-{ }^{14} \mathrm{C}\right]$ пальмитиновой кислотой, определяли радиоактивность липидных фракций. Установлено ингибирующее влияние холестерола в условиях повышения его уровня в рационе белых крыс и морских свинок на синтез всех классов липидов в жировой ткани in vitro при использовании в качестве предшественников [6- $\left.{ }^{14} \mathrm{C}\right]$ глюкозы и $\left[2-{ }^{14} \mathrm{C}\right]$ лизина и на синтез холестерола при применении в качестве предшественника [1- $\left.{ }^{14} \mathrm{C}\right]$ пальмитиновой кислоты.

КЛЮЧЕВЫЕ СЛОВА: липиды, холестерол, крысы, морские свинки, жировая ткань, гиперхолестеролемия.

Received 15.01.15

Address for correspondence: O. S. Pokotylo, Ivan Puliuy Ternopil National Technical University, Tantsorova St., 2, Ternopil, 46001, Ukraine, e-mail: pokotylo_oleg@ukr.net. 